\title{
Morphology and Thermal Properties of Poly(3-hydroxybutyrate-co-3-hydroxyvalerate)/Attapulgite Nanocomposites
}

\author{
Rossana Mara da Silva Moreira Thiréa,b*, Liliane Cardoso Arruda ${ }^{\mathrm{a}}$, Ledjane Silva Barreto ${ }^{\mathrm{a}}$ \\ aPrograma de Pós-Graduação em Ciência e Engenharia de Materiais - PCEM, \\ Universidade Federal de Sergipe - UFS, CEP 49100-000, São Cristóvão, SE, Brazil \\ ${ }^{\mathrm{b}}$ Programa de Engenharia Metalúrgica e de Materiais - PEMM/COPPE, \\ Universidade Federal do Rio de Janeiro - UFRJ, \\ CP 68505, CEP 21945-970, Rio de Janeiro, RJ, Brazil
}

Received: March 16, 2011; Revised: May 24, 2011

\begin{abstract}
Poly(3-hydroxybutyrate-co-3-hydroxyvalerate)-PHBV is a biodegradable polyester which has been studied as an option for the production of disposable goods. Attapulgite is a fibrous clay mineral. The aim of this work was to produce and characterize renewable resource derived-nanocomposites based on PHBV and organophilic attapulgite (MAT). The nanocomposites were characterized by XRD, SEM and thermal analysis. It was observed reduction in degree of crystallinity, in melting and glass transition temperatures and in thermal stability of polymer due to the addition of clay to PHBV matrix. The best results were obtained for PHBV films containing 3 and $5 \%$ MAT. These films presented a slight increase in processing window and decrease in crystalline temperature and in degree of crystallinity as compared to pure PHBV.
\end{abstract}

Keywords: $P H B V$, attapulgite, nanocomposites, biodegradable polymer

\section{Introduction}

In the last decade, there has been increasing concern over the harmful effects of conventional synthetic plastic materials in the environment. This ecological awareness stimulated the development of new biodegradable materials, especially for single-use plastic items. Poly (3-hydroxybutyrate) (PHB) and its copolymer poly (3-hydroxybutyrate-co-3-hydroxyvalerate) (PHBV) have attracted much attention as biocompatible and biodegradable thermoplastics with potential application in agriculture, marine and medicine fields. They are natural polyesters produced by various microorganisms in the form of intracellular granules as reserve material of carbon and energy. Despite of presenting properties similar to isotactic polypropylene, there are some limitations that hamper the wider scale application of PHBV, such as: high crystallinity, narrow processing window and higher production cost as compared to traditional polymers $^{1}$. Moreover, the inclusion of $\mathrm{HV}$ units in the PHB crystalline lattice reduced nucleation and linear growth rate. Thus, PHBV presents low crystallization rates as compared to the time scale of most industrial moulding and fabrication process ${ }^{2}$.

PHB and PHBV nanocomposites filled with layered clay such as montmorillonite, sepiolita and hectorite have been studied ${ }^{2-7}$. It was observed that the incorporation of clay to the polymeric matrix improves mechanical behaviour, thermal properties, gas barrier properties and biodegradation rates of the material as compared to neat polymer. The main advantage of nanocomposites is that enhanced properties can be obtained with a small amount of filler due to the large contact area between polymer and clay.

Attapulgite, also known as palygorskite, is a clay mineral characterized by a short fibrous morphology ${ }^{8}$. It has a threedimensional structure composed of channels of about $3.7 \times 6.4 \AA$, which have exchangeable cations and water. The presence of channels and micropores in attapulgite structure together with fine particle size provides a large surface area, estimated at about $150 \mathrm{~m}^{2} \cdot \mathrm{g}^{-1[8]}$.
Attapulgite has been also used as nanofiller to improve properties of several polymers, such as polyuretane ${ }^{9}$, polypropylene ${ }^{10}$ and polyamide $6^{11}$.

The aim of this work was to prepare and characterize PHBV/ organophilic attapulgite (MAT) nanocomposites. The effect of MAT on the morphology and thermal properties of PHBV was investigated by scanning electron microscopy (SEM), X-ray diffraction (XRD), differential scanning calorimetry (DSC) and thermogravimetric analysis (TGA).

\section{Experimental}

\subsection{Materials}

Poly(3-hydroxyvbutyrate-co-3-hydroxyvalerate) - Biocycle ${ }^{\mathrm{TM}}$ 2000 (code L-109) was kindly supplied by PHB Industrial S/A (São Paulo, Brazil) and was used as received. PHBV presents HV contents and weight average molecular weight $\left(\mathrm{M}_{\mathrm{w}}\right)$ of $4.07 \mathrm{wt}$. (\%) and 394,984 g.mol ${ }^{-1}$, respectively. Attapulgite was obtained from State of Piauí, Brazil.

\subsection{Preparation of nanocomposites}

Attapulgite was organically modified according to the following procedure. Attapulgite was gradually added to a hexadecyltrimethylammonium chloride solution at $80{ }^{\circ} \mathrm{C}$ and vigorously stirred for 3 hours. The treated inorganic material was plenty washed with distilled water. The filtrate was titrated with $0.1 \mathrm{~N}$ $\mathrm{AgNO}_{3}$ until no further formation of $\mathrm{AgCl}$ precipitated to ensure the complete removal of chloride ions. The filter cake was then placed in a vacuum oven at $80{ }^{\circ} \mathrm{C}$ for 5 hours. The dried cake was ground with mortar and pestle and screened with a 325-mesh sieve to obtain the organophilic clay (MAT). 
The nanocomposites were prepared by solution intercalation method ${ }^{6}$. PHBV was heat-dissolved in chloroform for 2 hours at $65^{\circ} \mathrm{C}$ in order to obtain a 7\% w/v PHBV solution. 1-5 wt. (\%) of MAT was added to the polymer solution. The resulting mixture was vigorously stirred and then aged for 3 days with occasional shaking. After this period, the suspension was heated for 1 hour at $60{ }^{\circ} \mathrm{C}$, spread on glass moulds and allowed to dry at room temperature until complete evaporation of the solvent. The nanocomposites were stored at room conditions for at least 20 days prior to characterization analysis. Preliminary tests indicated that within this period samples achieved plateau of crystallinity due to secondary crystallization.

\subsection{Characterization}

$\mathrm{X}$-ray diffraction analysis of attapulgite and nanocomposites was carried out with a Rigaku-Miniflex diffratometer, operated with $\mathrm{CuK} \alpha$ wavelength of $15.42 \mathrm{~nm}$. Data were acquired at ambient temperature in the angular region $(2 \theta)$ of $3-40^{\circ}$ (scanning speed $=2 \%$ minute). The morphology of the fractured surface of PHBV/MAT films was evaluated using a JEOL JSM-6460LV SEM equipment with an acceleration voltage of $15 \mathrm{kV}$. The samples were fractured in liquid nitrogen and then were coated with a thin layer of gold prior to SEM observation. Thermogravimetric analysis (TGA) was carried out using a SDT 2960 Simultaneous DSC-TGA instrument under nitrogen flow of $100 \mathrm{~mL} / \mathrm{min}$ at a heating rate of $10{ }^{\circ} \mathrm{C} / \mathrm{min}$ from room temperature to $400^{\circ} \mathrm{C}$. DSC experiments were performed using a Perkin Elmer Pyris 6 Differential Scanning Calorimeter. Nitrogen was used as the purge gas for the DSC cell. Samples of about $3 \mathrm{mg}$ were weighed and sealed in the aluminum DSC pans and placed in the DSC cell. They were first heated from room temperature to $200{ }^{\circ} \mathrm{C}$ at a rate of $10{ }^{\circ} \mathrm{C} / \mathrm{min}$. The samples were kept at $200{ }^{\circ} \mathrm{C}$ for 2 minutes and subsequently cooled to $-20^{\circ} \mathrm{C}$ at $40^{\circ} \mathrm{C} / \mathrm{min}$. Then, the samples were re-heated to $200^{\circ} \mathrm{C}$ at a rate of $10^{\circ} \mathrm{C} / \mathrm{min}$. The thermal parameters were obtained from the second heating scan. The degree of crystallinity of PHBV in PHBV/MAT films (Xc) was estimated according to the Equation 1:

$$
\mathrm{Xc}(\%)=\left[\Delta \mathrm{H}_{\mathrm{f}} /\left(\mathrm{W}_{\mathrm{PHBV}} * \Delta \mathrm{H}_{\mathrm{f}}^{\mathrm{ref}}\right)\right]^{*} 100
$$

where $\Delta \mathrm{H}_{\mathrm{f}}$ is the enthalpy of fusion of sample, $\mathrm{W}_{\text {PHBV }}$ is the weight fraction of PHBV in the sample and $\Delta \mathrm{H}_{\mathrm{f}}^{\text {ref }}$ is the enthalpy of fusion of $100 \%$ crystallized PHBV, $146 \mathrm{~J}^{-\mathrm{g}^{-1[12]}}$.

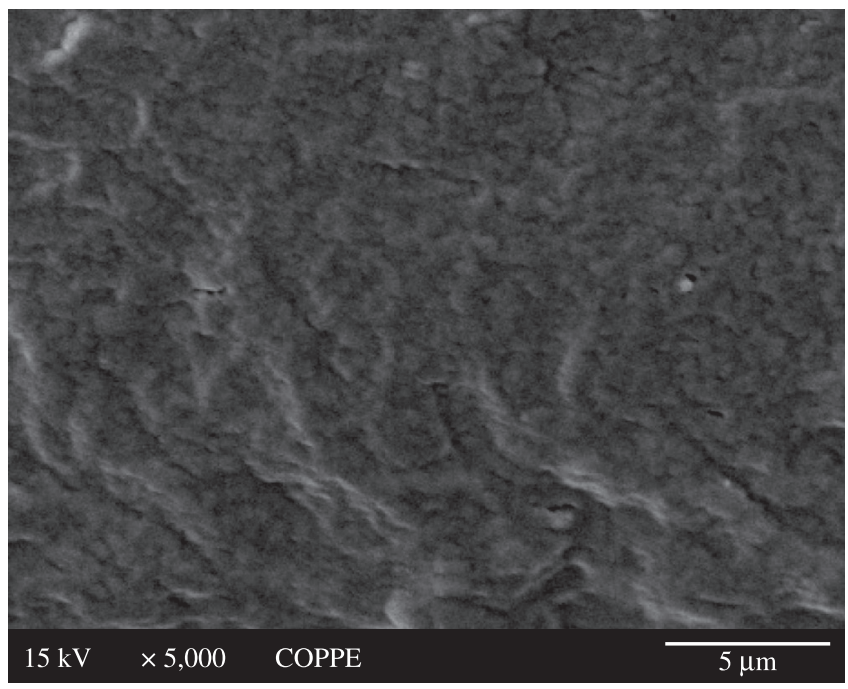

(a)

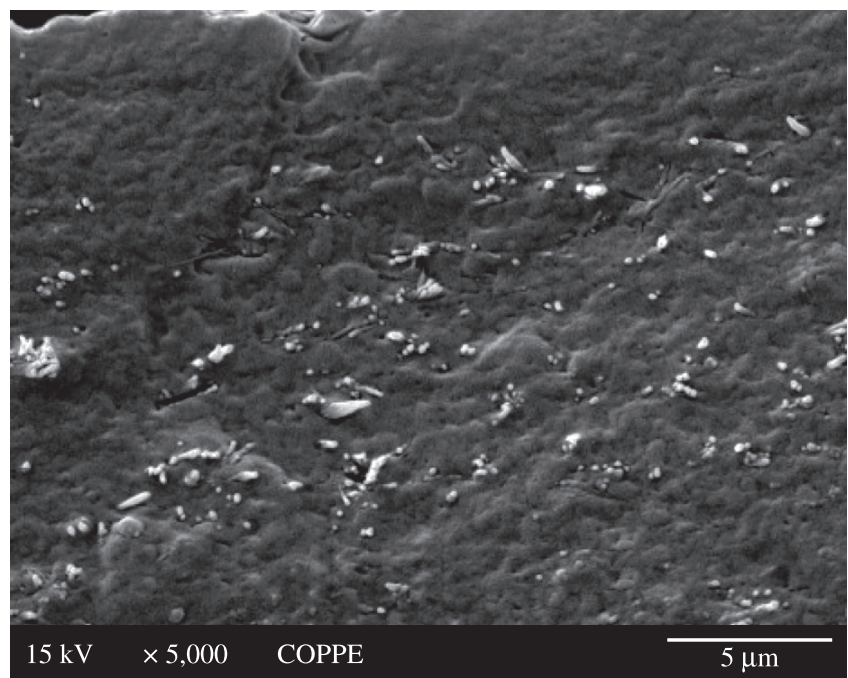

(c)

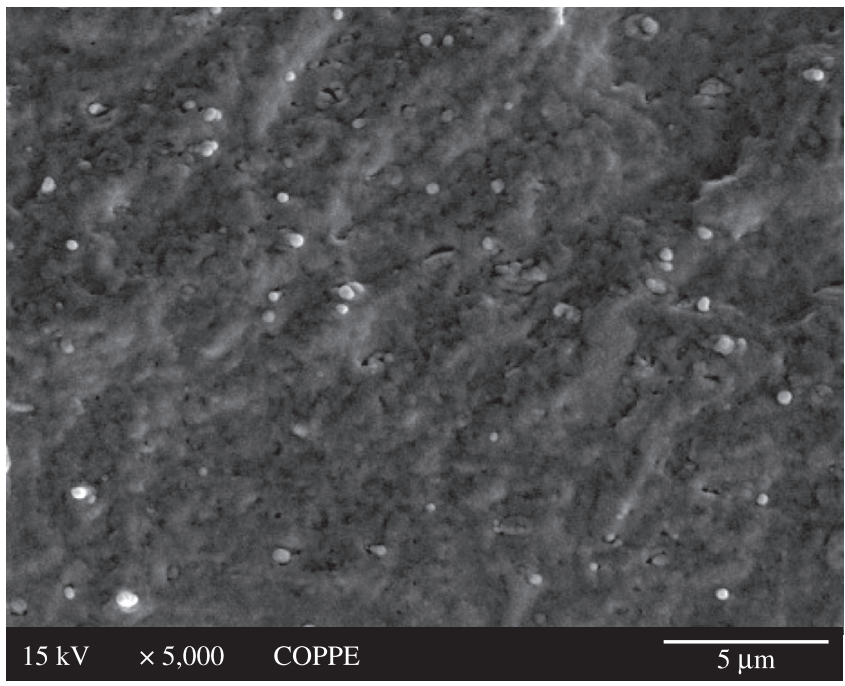

(b)

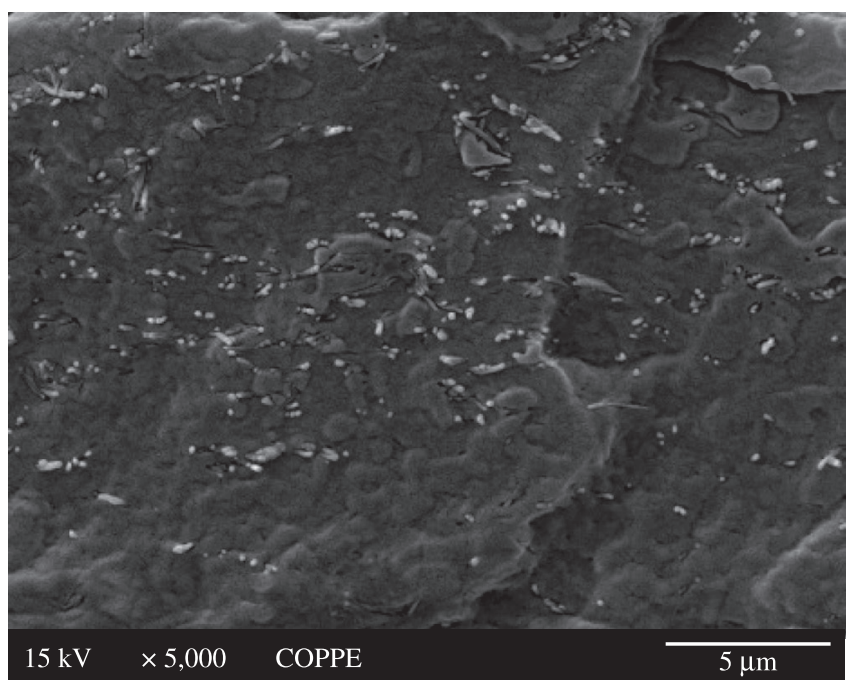

(d)

Figure 1. SEM images of the fractured surface of PHBV films: a) pure PHBV; b) PHBV/1\%MAT; c) PHBV/3\%MAT; and d) PHBV/5\%MAT. 


\section{Results and Discussion}

Figure 1 shows SEM images of typical regions of fractured surface of pure PHBV (a) and PHBV/MAT nanocomposites (b-d) films. White dots with nanometric and submicrometric in size can be visualized on the fractured surface of films containing 1\% MAT (Figure 1b). These features can be attributed to the cross section of attapulgite bundles, which might be orientated in a parallel direction to the external surface of nanocomposite. These features are homogenously distributed within polymer matrix. The image of the fractured surface of PHBV/5\%MAT (Figure 1c) shows smaller white dots but in this case, they are arranged in micrometric agglomerates. These agglomerates are non-homogenously dispersed within PHBV matrix. Moreover, elongated features which are mostly arranged in large micrometric agglomerates can be also visualized. These features might be attributed to attapulgite fibrils which are perpendicularly oriented in relation to external surface of the film. In some regions, voids around agglomerates are observed, indicating poor filler-matrix interface. The PHBV/3\%MAT fractured surface (Figure 1b) presents intermediate morphology, since several submicrometric white dots along with micrometric fibrils agglomerates can be visualized.

$\mathrm{X}$-ray diffraction patterns of PHBV films and PHBV/MAT nanocomposites are presented in Figure 2a. The diffraction profile of PHBV sample is very similar of that presented for PHB homopolymer. This similarity was expected due to the low $3 \mathrm{HV}$ content of PHBV employed in this work ${ }^{12}$. The profile exhibits well-defined peaks $(2 \theta)$ at $13.6^{\circ}, 17.1^{\circ}, 21.7^{\circ}, 22.7^{\circ}, 25.6^{\circ}$ and $30.7^{\circ}$, which correspond to the (020), (110), (101), (111), (121) and (002) reflections of the orthorhombic crystalline lattice, respectively. It can be observed that the peak positions remain practically unchanged in PHBV/ MAT diffractograms. This fact suggests that the PHBV crystalline lattice do not change appreciably in the presence of attapulgite. The characteristic peak of attapulgite which appears at $2 \theta=8.42^{\circ}$ can be observed in PHBV/MAT nanocomposites diffraction patterns. This peak is attributes to the primary diffraction of the (110) crystal face ${ }^{2}$. Different from layered clay such as montmorillonite, whose diffraction peak shift significantly when clay aggregated/exfoliated, the attapulgite characteristic peak remains unchanged in nanocomposites, since unit layers in an attapulgite single crystal cannot be further separated. Similar to others polymeric nanocomposites ${ }^{11}$, it can also be noted that the intensity of this characteristic peak increases in a function of the amount of MAT presents in sample.

Figure $2 b$ shows DSC curves of second heating scan for PHBV and its nanocomposites. Table 1 summarizes the thermal properties obtained from this scan. Owing to the melting point of attapulgite being much higher than $1500{ }^{\circ} \mathrm{C}$, DSC curves showed only the properties of PHBV matrix. The glass transition temperature ( $\mathrm{Tg}$ ) of the nanocomposites with $1 \%$ MAT increased as compared to PHBV films. Probably, the mobility of PHBV chains was constrained due to clay-PHBV interaction. This filler-matrix interaction might be related to the homogenous distribution of filler. On the contrary, the incorporation of higher amount of MAT led to a decrease in $\mathrm{Tg}$ for PHBV/3\%MAT and PHBV/5\%MAT. In these cases, the constrained

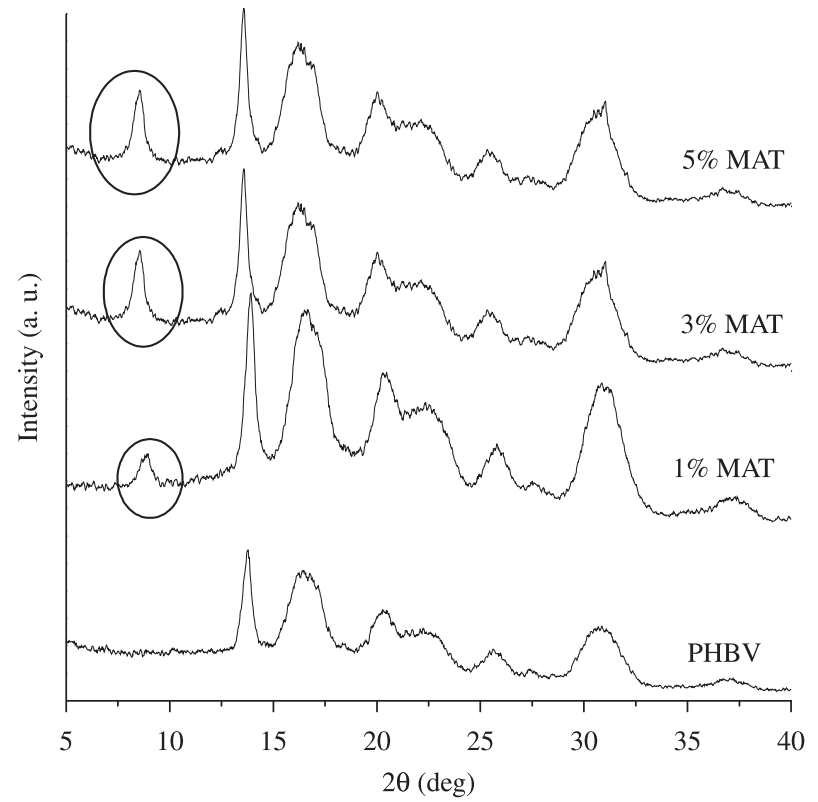

(a)

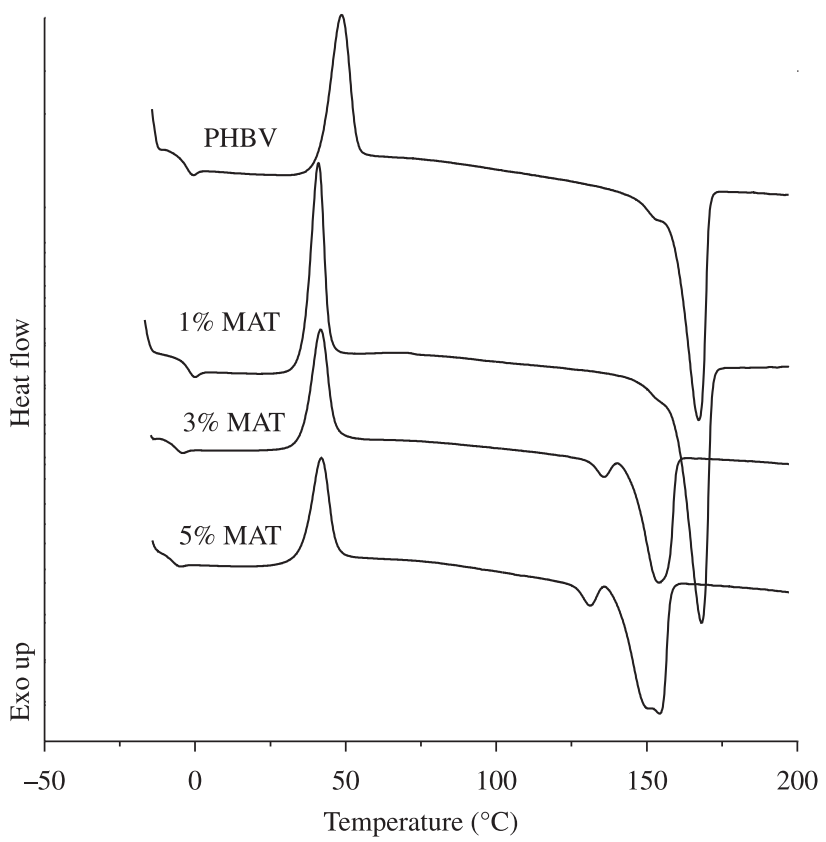

(b)

Figure 2. a) XRD diffraction patterns and b) DSC thermograms of second heating scan for pure PHBV and PHBV/MAT nanocomposites.

Table 1. Thermal properties obtained from DSC heating curves of second heating scan for pure PHBV and its nanocomposites with 1,3 and 5\%MAT.

\begin{tabular}{|c|c|c|c|c|c|c|c|c|}
\hline Amostra & $\operatorname{Tg}\left({ }^{\circ} \mathrm{C}\right)$ & $\mathrm{T}_{\mathrm{c}}\left({ }^{\circ} \mathrm{C}\right)$ & $\Delta \mathrm{H}_{\mathrm{c}}(\mathrm{J} / \mathrm{g})$ & $1^{\circ} \mathrm{T}_{\mathrm{f}}\left({ }^{\circ} \mathrm{C}\right)$ & $1^{\circ} \Delta \mathrm{H}_{\mathrm{f}}(\mathrm{J} / \mathrm{g})$ & $2^{\circ} \mathrm{T}_{\mathrm{f}}\left({ }^{\circ} \mathrm{C}\right)$ & $2^{\circ} \Delta \mathrm{H}_{\mathrm{f}}(\mathrm{J} / \mathrm{g})$ & $X_{c}(\%)$ \\
\hline PHBV & $-2.03 \pm 0.53$ & $46.15 \pm 1.82$ & $-39.42 \pm 6.34$ & $168.58 \pm 1.01$ & $69.00 \pm 8.81$ & - & - & $53.7 \pm 7.5$ \\
\hline PHBV/1\%MAT & $-1.65 \pm 0.37$ & $40.91 \pm 0.01$ & $-32.36 \pm 0.34$ & $168.24 \pm 0.01$ & $58.85 \pm 2.60$ & - & - & $40.7 \pm 1.8$ \\
\hline PHBV/3\%MAT & $-5.59 \pm 0.26$ & $41.82 \pm 0.13$ & $-32.36 \pm 1.37$ & $135.83 \pm 0.23$ & $3.46 \pm 0.01$ & $154.43 \pm 0.70$ & $57.11 \pm 3.55$ & $42.8 \pm 2.5$ \\
\hline PHBV/5\%MAT & $-6.61 \pm 0.01$ & $41.98 \pm 0.13$ & $-22.12 \pm 4.63$ & $130.91 \pm 0.13$ & $3.36 \pm 0.64$ & $154.29 \pm 0.01$ & $47.63 \pm 5.98$ & $36.8 \pm 4.8$ \\
\hline
\end{tabular}




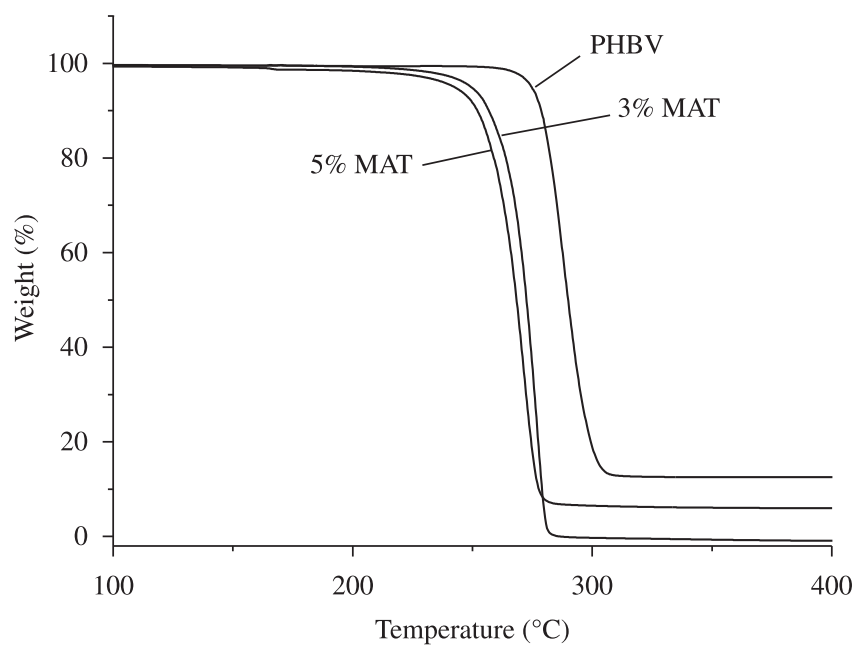

(a)

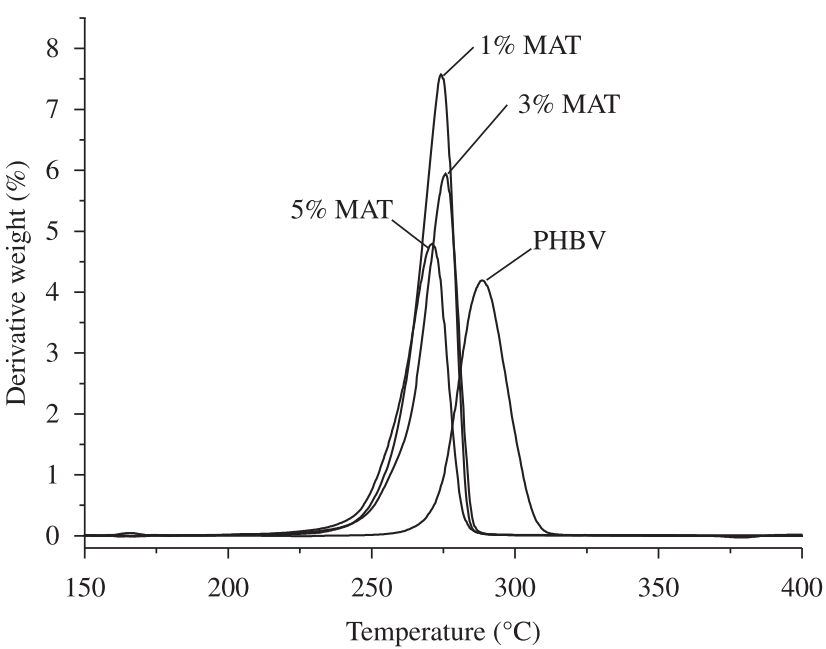

(b)

Figure 3. a) TG and b) DTG curves for pure PHBV and PHBV/MAT nanocomposites.

action of MAT was reduced and the agglomeration of filler might become a predominant factor for Tg decreasing.

For all samples, the presence of attapulgite reduced the crystallization temperature (Tc), indicating an enhanced crystallization ability of PHBV. It can be inferred that the attapulgite acted as nucleation agent during the nonisothermal crystallization process. It was already observed that several nanofillers can act as nucleating agent in PHB or PHBV matrix, such as organically modified montimorillonite (Cloisite 15B $)^{5}$, cellulose nanowhiskers ${ }^{13}$ and lignin fine powder ${ }^{14}$. In these cases, the filler reduces the energy barrier for polymer crystallization and increases the nucleating density, originating smaller spherulites in higher number than those of neat PHB or PHBV.

There was a decrease in the melting temperature $(\mathrm{Tm})$ of the nanocomposites compared with pure PHBV, excepted for PHBV/1\%MAT nanocomposites. The presence of clay seemed to induce crystals defects and/or reduce crystallite sizes, which led to lower melting temperature in relation to neat $\mathrm{PHBV}^{2,6}$. However, Pan et al. ${ }^{11}$ considered that the decrease in Tm of polyamide 6 nanocomposites containing $8 \%$ attapulgite as compared to pure polyamide 6 was resulted from the reduction of filler-matrix interaction. For films with 3 and 5\% MAT, there was a formation of two distinct populations of crystals, as evidenced by the presence of two endothermic peaks in DSC curve. This observation suggests that the formation of crystals with larger imperfections and/or smaller crystals, which melted at lower temperatures. According to Wang et al. ${ }^{4}$, the lower temperature peak corresponded to the melting of the crystals formed at the crystallization temperature while the higher temperature was related to the crystals rearranged during heating in the calorimeter.

The presence of attapulgite reduced the crystallinity degree $\left(\mathrm{X}_{\mathrm{c}}\right)$ of PHBV (Table 1). However, the amount of MAT did not influenced significantly $X_{c}$ values for nanocomposites. In the case of PHBV/1\%MAT, $\mathrm{X}_{\mathrm{c}}$ might be reduced due to the restriction of the mobility of PHBV chains. Concerning the presence of 3 and 5\% MAT, although the PHBV chains gained mobility in these nanocomposites, as shown by Tg values, the packaging of PHBV chains in crystalline regions might be impaired by the presence of clay particles with different orientations and not well-dispersed in matrix.

The influence of attapulgite on the thermal stability of the nanocomposites was investigated by TGA analysis (Figure 3 and
Table 2. TGA results for pure PHBV and PHBV/MAT nanocomposites films: onset temperature $\left(\mathrm{T}_{\text {onset }}\right)$ and endset temperature $\left(\mathrm{T}_{\text {endset }}\right)$ of the degradation process and temperature of maximum rate of weight loss $\left(\mathrm{T}_{\mathrm{d}}\right)$.

\begin{tabular}{lccc}
\hline \multicolumn{1}{c}{ Sample } & $\mathrm{T}_{\mathrm{d}}\left({ }^{\circ} \mathrm{C}\right)$ & $\mathrm{T}_{\text {onset }}\left({ }^{\circ} \mathrm{C}\right)$ & $\mathrm{T}_{\text {endset }}\left({ }^{\circ} \mathrm{C}\right)$ \\
\hline PHBV & 285.9 & 276.8 & 294.9 \\
PHBV/1\%MAT & 274.2 & 264.7 & 279.1 \\
PHBV/3\%MAT & 275.7 & 265.5 & 280.6 \\
PHBV/5\%MAT & 274.9 & 260.9 & 277.0 \\
\hline
\end{tabular}

Table 2). In Figure 3a, the mass plots of samples are shown, while the corresponding derivative of the data (DTG curves) is presented in Figure 3b. The temperature of maximum rate of weight loss (Td), the onset temperature $\left(\mathrm{T}_{\text {onset }}\right)$ and the endset temperature $\left(\mathrm{T}_{\text {endset }}\right)$ of samples are listed in Table 2 .

The TGA curve of pure PHB exhibits a single degradation step with onset temperature at $272.7^{\circ} \mathrm{C}$. A single peak observed in DTG curve confirms this degradation profile and indicates that the maximum rate of mass loss was achieved at $288.5^{\circ} \mathrm{C}$. It is well known that thermal degradation of PHBV occurs almost exclusively by a nonradical random chain scission mechanism involving a sixmembered ring transition state ${ }^{15}$.

The thermal degradation process of PHBV/MAT nanocomposites also occurs in only one weight loss step. Nevertheless, in the presence of clay the curves are shifted to lower temperatures indicating a decreasing in thermal stability of nanocomposites compared to pure PHBV. The onset temperature $\left(\mathrm{T}_{\text {onset }}\right)$ was more affected since it was observed a shift of about $-20{ }^{\circ} \mathrm{C}$ in relation to neat PHBV. Probably the quaternary ammonium salts used as organophilic modifier enhanced the PHA degradation. It was proposed that the surfactant starts to decompose according to the Hofmann elimination reaction or a nucleophilic attack of the ammonium counter-ion on the ammonium. The decomposition products, amines or acidic protons, could then enhance the random chain scission reaction of $\mathrm{PHBV}^{16}$.

\section{Conclusion}

PHBV/attapulgite nanocomposites were successfully obtained by solution intercalation method. The use of organophilic attapulgite led to significant changes in PHBV properties. The presence of 
organophilic attapulgite induced PHBV crystallization at lower temperatures, probably acted as nucleating agent. This result may be important for attenuating the problems associated to secondary crystallization of PHBV. These films showed a reduction in degree of crystallinity and a decrease in melting and glass transition temperatures at concentrations of 3 and 5\%MAT in relation to unfilled PHBV. However, the incorporation of MAT may lead to an improvement in PHBV processing, since the range of the processing temperature of the nanocomposites $\left(\mathrm{T}_{\text {onset }}-\mathrm{T}_{\mathrm{m}}\right)$ increased slightly when compared to pure PHBV films. The attapulgite is presented as an environmentally friendly, naturally abundant and low cost material, which can be used to improve PHBV-based bioplastics properties and to reduce their cost.

\section{Acknowledgements}

The authors thank PHB Industrial S/A for the supply of PHBV and the Brazilian agencies CNPq, CAPES and FAPERJ for financial support.

\section{References}

1. Hodzic A. Bacterial Polyester-Based Biocomposites: A Review. In: Mohanty AK, Misra M and Drzal LT, editors. Natural Fibers, Biopolymers, and Biocomposites. Boca Raton: CRC Press; 2005. chap 18. http://dx.doi.org/10.1201/9780203508206.ch18

2. Choi WM, Kim TW, Park OO, Chang YK and Lee JW. Preparation and Characterization of Poly(hydroxybutyrate-co-hydroxyvalerate)Organoclay Nanocomposites. Journal of Applied Polymer Science. 2003; 90:525-529. http://dx.doi.org/10.1002/app.12702

3. Chen G, Hao G, Guo T, Song M and Zhang B. Structure and mechanical properties of poly(3-hydroxybutyrate-co-3-hydroxyvalerate) (PHBV)/ clay nanocomposites. Journal of Material Science Letters. 2002; 21:1587-1589. http://dx.doi.org/10.1023/A:1020309330371

4. Wang S, Song C, Chen G, Guo T, Liu J, Zhang B et al. Characteristics and biodegradation properties of poly(3-hydroxybutyrate-co-3hydroxyvalerate)/organophilic montmorillonite (PHBV/OMMT) nanocomposites. Polymer Degradation and Stability. 2005; 87:69-76. http://dx.doi.org/10.1016/j.polymdegradstab.2004.07.008

5. Bruzaud $\mathrm{S}$ and Bourmaud $\mathrm{A}$. Thermal degradation and (nano)mechanical behavior of layered silicate reinforced poly(3-hidroxibutirato-co-valerate) nanocomposites. PolymerTesting. 2007; 26:652-659. http://dx.doi. org/10.1016/j.polymertesting.2007.04.001
6. Bordes P, Pollet E and Avérous L. Nano-biocomposites: Biodegradable polyester/nanoclay systems. Progress in Polymer Science. 2009; 34:125-155. http://dx.doi.org/10.1016/j.progpolymsci.2008.10.002

7. Botana A, Mollo M, Eisenberg P and Sanchez RMT. Effect of modified montmorillonite on biodegradable PHB nanocomposites. Applied Clay Science. 2010; 47:263-270. http://dx.doi.org/10.1016/j.clay.2009.11.001

8. Galan E. Properties and applications of palygorskite-sepiolite clays. Clay Minerals. 1996; 31:443-453. http://dx.doi.org/10.1180/ claymin.1996.031.4.01

9. Pan $\mathrm{H}$ and Chen D. Preparation and characterization of waterborne polyuretane/attapulgite nanocomposites. European Polymer Journal. 2007; 43:3766-3772. http://dx.doi.org/10.1016/j.eurpolymj.2007.06.031

10. Chen JJ, Chen JY, Zhu SP, Cao Y and Li HL. Mechanical Properties, Morphology, and Crystal Structure of Polypropylene/Chemically Modified Attapulgite Nanocomposites. Journal of Applied Polymer Science. 2011; 121:899-908. http://dx.doi.org/10.1002/app.33611

11. Pan B, Yue Q, Ren J, Wang H, Jian L, Zhang J et al. A study on attapulgite reinforced PA6 composites. Polymer Testing. 2006; 25:384-391. http://dx.doi.org/10.1016/j.polymertesting.2005.11.012

12. Mei-Ling $\mathrm{C}$ and Yi-Ming $\mathrm{S}$. Relationship between free volume properties and structure of poly(3-hydroxybutyrate-co-3-hydroxyvalerate) membranes via various crystallization conditions. Polymer. 2009; 50:5298-5307. http://dx.doi.org/10.1016/j.polymer.2009.09.035

13. Jiang L, Morelius E, Zhang J, Wolcott M and Holbery J. Study of the Poly(3-hydroxybutyrate-co-3-hydroxyvalerate)/Cellulose Nanowhisker Composites Prepared by Solution Casting and Melt Processing. Journal of Composite Materials, 2008; 42: 2629-2645. http://dx.doi. org/10.1177/0021998308096327

14. Weihua K, He Y, Asakawa N and Inoue Y. Effect of Lignin Particles as a Nucleating Agent on Crystallization of Poly(3-hydroxybutyrate). Journal of Applied Polymer Science. 2004; 94:2466-2474. http://dx.doi. org/10.1002/app.21204

15. Liu Q-S, Zhu M-F, Wu W-H and Qin Z-Y. Reducing the formation of sixmembered ring ester during thermal degradation of biodegradable PHBV to enhance its thermal stability. Polymer Degradation and Stability. 2009; 94:18-24. http://dx.doi.org/10.1016/j.polymdegradstab.2008.10.016

16. Bordes P, Hablot E, Pollet E and Avérous L. Effect of clay organomodifiers on degradation of polyhydroxyalkanoates. Polymer Degradation and Stability. 2009; 94:789-796. http://dx.doi.org/10.1016/j. polymdegradstab.2009.01.027 